\title{
DETERMINANT FACTORS THAT INFLUENCE ENTREPRENEURIAL INTENTION AMONG STUDENTS IN MALAYSIA
}

\author{
Lu Man Hong ${ }^{1 *}$, Muhammad Azim Abu Hassan Sha'ari², Wan Farha Wan Zulkiffli³, Roslizawati Che \\ Aziz $^{4}$, Mohammad Ismail ${ }^{5}$ \\ 1,2,3,4,5 Faculty of Business and Entrepreneurship, Universiti Malaysia Kelantan, Malaysia \\ Email: ${ }^{1}$ vicklumanhong@gmail.com; ${ }^{2}$ azimabuhassan@gmail.com; ${ }^{3}$ farha@umk.edu.my; ${ }^{4}$ roslizawati@umk.edu.my; \\ ${ }^{5}$ mohammad.i@umk.edu.my \\ *Corresponding author
}

\begin{abstract}
This research tent to examine the factors that influence entrepreneurial intention among diploma student at Kolej Islam Antarabangsa Sultan Ismail Petra (KIAS) by using The Theory of Planned Behavior (TPB) which indicated that (attitude, subjective norms, perceived behavioral control, and entrepreneurial education) as the independent variables while entrepreneurial intention is the dependent variable. Quantitative research design had been designed where 100 set of questionnaires had been distributed to target respondents in order to get the necessary information. All data were analyzed using SmartPLS software. The finding showed that attitude and entrepreneurial education were significant towards entrepreneurship intention. The findings were insightful for universities to better understand the motivation and intention of their students as well as enhancing and designing the entrepreneurial course offering as to be more proactive enough. Furthermore, this study provided future research opportunity by using the same model to carry out a similar study in different places.
\end{abstract}

Keywords: Attitude; entrepreneurial intention; entrepreneurial education; perceived behavioral control; subjective norms.

\section{Introduction}

Entrepreneurship can be a procedure to generate new venture and new organization (Tran \& Von Korflesh, 2016). Hence, entrepreneurship became the main indicator for economic growth since entrepreneurial activity capable to job creation, innovation encouragement, and reduce of unemployment (Ogunlana, 2018; Fritsch, Kritikos, \& Pijnenburg, 2015). Based on Dass (2018), although GDP for Malaysia rose $6 \%$ continuously in three years, unemployment rate achieved $3.4 \%$ in 2017 especially unemployment rate for youth was reached $13.2 \%$. This indicated that unemployment rate was not reduced although GDP in Malaysia was increase. Soraya, Pang, Aishah and Zubaibad (2015) pointed out that increase number of graduated from higher education institution became trigger for youth became unemployment. Many higher education institutions include KIAS started provided entrepreneurship as main course subject. This is due to entrepreneurship became guild line for fresh graduates to seek business foundation as career as recommended from Soraya et al. (2015).

A study from Taha, Ramlan, and Noor (2017) appended entrepreneurship intention can be one of the measurements for entrepreneurial behavior or new business creation action. On top of that, it can be supported by the study from Kabir, Haque, and Sarwar (2017) suggested entrepreneurial education as one of measurement for entrepreneurial intention based on TPB theory.
Since the framework of this study is based on TPB theory by Ajzen (1991) which indicated three variables (attitude, subjective norms, and perceived behavioral control) formed as independent variables in this study.

However, this study added entrepreneurial education added as one of the independent variables since KIAS provided entrepreneurship as main core subjects in course structure. Furthermore, graduates have been recommended to broaden their field of vision by looking into business as a probable foundation for a career. As fact, entrepreneurship will assist the fresh graduates to exploit their own undertaking and reduce the unemployment problem by broaden and wider the job market (Soraya et al., 2015).

Therefore, the researchers believe that this study can improve knowledge and entrepreneurial intention by identify the factor influence entrepreneurial intention particularly among diploma student at Kolej Islam Antarabangsa Sultan Ismail Petra (KIAS), Kelantan, Malaysia. This due to KIAS provided entrepreneurship as main core subjects in course structure among their diploma students.

\section{Entrepreneurial Intention}

Ajzen (1991) and Kabir et al. (2017) explained intention is a great predictor towards willingness from an individual to perform a behavior. Based on Joseph (2017) and Noor, Hong, Zakaria, Nik Mud, and Yunoh (2019), entrepreneurial intention defined as a mindset 
from individuals to achieve a specific business target based on past experience, action, and attention. Nathani and Dwivedi (2019) and Ismail, Ibrahim, Yaacob, Ibrahim, Zakaria, Razak, Yusoff, Guan, and Kamaruddin (2018) given further explanation for entrepreneurial intention as a mental orientation for individuals include hope, wish, and desire that affect the choice for entrepreneurship.

Many past researchers identifying intention as measurement for willingness from an individual to perform a behavior in variety fields (Mohamad, Lim, Yusof, \& Soon, 2015). However, intention have variety explanation from past researchers in entrepreneurial study such as Usman and Yennita (2019), Kabir et al. (2017), Tsordia, and Papadimitriou (2015) appended that an individual intent to become entrepreneurial due to the factors of attitude, perceived behavioral control, social influence, and entrepreneurial education. Therefore, the entrepreneurial intention in this study defined as the self-acknowledged belief from individual that create out new business in future (Botha, Carruthers, \& Venter, 2019).

\section{Attitude}

According to Ajzen (1991), attitude defined as the perception from an individual towards certain a behavioral neither in positive or negative. As Kabir et al. (2017) appended attitude significantly related to personal intention which directly towards behavioral intention. Kabir et al. (2017) given further explanation which appended individuals' attitude and intention can be designed and given impact to participate as entrepreneur. In order words, individual starting a business based on the reaction of individuals' attitude neither in positive or negative (Taha et al., 2017).

The finding from Gitaka (2018) appended attitude positive related towards entrepreneurial intention among students. Another study from Gitonga (2017) found that attitude was positively and significant towards entrepreneurial intention among students in United States International University (USIU) in Africa. Furthermore, a similar study conducted by Usman (2016) and found out that attitude was positively and significant towards entrepreneurial intention among Muslim undergraduate students who took entrepreneurship course in USIU. On top from that, university students have great intent to become entrepreneur if they have positive attitude towards entrepreneurial activities.

In summary, the hypothesis between attitude and entrepreneurial intention in this study stated as below:

$H_{l}$ : Attitude has positive influence towards entrepreneurial intention among KIAS students.

\section{Subjective Norms}

In terms of subjective norms, social influence become main determinants to affect intention towards behavior including entrepreneur (Ajzen, 1991; Kabir et al., 2017). In order words, individual will evaluate and perform behavior based on the value perception from third parties towards that behavior (Ibrahim \& Afifi, 2018). Da Cruz, Suprapti, and Yasa (2015) explained the level of individuals believe neither follow peoples' advice or advice become determinants to participate entrepreneurial activities. Therefore, the supportive from third parties include friends, family members, and social group members become stimulate towards entrepreneurial intention for an individual.

The study from Benachenhou, Arzi, and Omar (2017) found out that motivation from outsiders become a trigger for an individual intent to open a new firm. Furthermore, Cavazos-Arroyo, Puente-Diaz, and Agarwal (2017) and Usman (2016) found that there is positive and significant relationship between subjective norms and entrepreneurial intention. Both researchers further explained that intention from individual become entrepreneur increase when many positive motivations from third parties. Therefore, the supportive from third parties includes friends, family members, and social group members become stimulate towards entrepreneurial intention for an individual. In summary, the hypothesis between subjective norms and entrepreneurial intention in this study stated as below:

$\mathrm{H}_{2}$ : Subjective norms has positive influence towards entrepreneurial intention among KIAS students.

\section{Perceived Behavioral Control}

Perceived behavioral control defined as the mindset of an individual has capability or the level of difficulty obtained when carry out that behavioral (Ajzen, 1991). In terms of entrepreneurial study, Dinc and Budic (2016) defined perceived behavioral control as the mindset of an individual for capability for running a company. Furthermore, Rengiah and Sentosa (2016) refer perceived behavioral control as the perception of easy or difficulty in order to fulfil for new business developing. Kabir et al. (2017) added perceived behavioral control is important trigger for entrepreneurial intention since it explained the strength of individuals' ability to perform entrepreneur's role, task, and activities.

Two past studies (Dinc \& Budic, 2016; Gitaka, 2018) revealed positive and significant relationship between perceived behavioral control and entrepreneur intention. Besides, Gitonga (2017) appended perceived 
behavioral control become strongest determinants for entrepreneurial intention. Furthermore, a study from Tsai, Chang, and Peng (2014) appended perceived behavioral control was positive affected entrepreneurial intention among students. In summary, the hypothesis between attitude and entrepreneurial intention in this study stated as below:

$H_{3}$ : Perceived Behavioral Control has positive influence towards entrepreneurial intention among KIAS students.

\section{Entrepreneurial Education}

In current decade, many education institutions have embarked the entrepreneurship course and programs besides its growth rapidly (Walter \& Block, 2016). Entrepreneurial education refers to the skills and the characteristic that should be developed to individuals in order to help them in creating new and innovation plan (Kabir et al., 2017). Therefore, the researchers justify that entrepreneurial characteristics among students can be developed through education to create a new venture with innovativeness. In result, entrepreneurial education become independent variable in this study.

Joseph (2017) explained entrepreneurial education capable to influence entrepreneurial intention among international students to became entrepreneur. This is significant to the study from Zhang, Wei, Sun, and Tung (2019) appended students were high intent to became entrepreneurial if learning activities based on entrepreneurial occur.

Ferreras-Garcia, Hernández-Lara, and SerradellLópez (2019) explained entrepreneurial education has capability to impact the creation of entrepreneurial mentality. Furthermore, Zhang et al. (2019) added there are significant different between students who either have or have not took entrepreneurial courses towards entrepreneurship intention. Furthermore, Kabir et al. (2017) proved that there is a relationship between entrepreneurial education and entrepreneurial intention. In summary, the hypothesis between entrepreneurial education and entrepreneurial intention in this study stated as below:

$H_{4}$ : Entrepreneurial education has positive influence towards entrepreneurial intention among KIAS students.

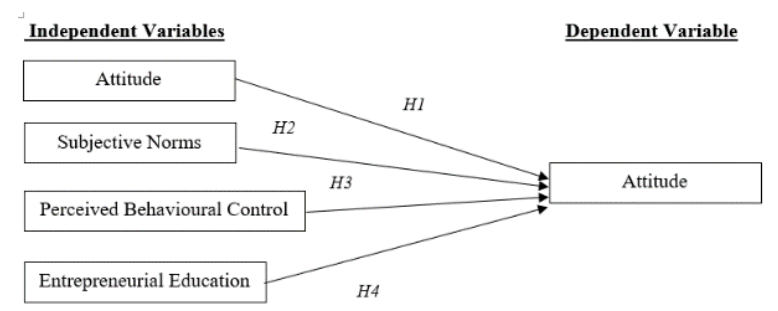

Figure 1. The conceptual research framework

\section{Research Methods}

A quantitative approach design was applied and 100 KIAS students has been selected as a target respondent in this study by using simple random probability method. All items in this study are designed in straightforward manners besides two languages which are English and Malay provided to reduce the confusion among target respondents. The questionnaire in this study consists three parts: Part A to collect demographic profile from target respondents; Part $B$ is to identify the feedback of target respondents towards entrepreneurial intention; Part $C$ is to identify the feedback of target respondents towards attitude, subjective norms, perceived behavioral control, and entrepreneurial education. Five-point Likert-scale was designed for Part $\mathrm{B}$ and Part $\mathrm{C}$ while nominal scale was designed in Part A.

All responses are collected by using Google Form and been analysis by SPSS 22.0 version and SmartPLS 3.0 software. Frequency analysis for demographic profile was ran by SPSS software while measurement model analysis, Fornell-Lacker criteria analysis, and path coefficient analysis were running by SmartPLS software.

The main objectives for measurement model analysis and Fornell-Lacker criteria analysis is to identify all items and variables in this study was reliable, valid, and least multicollinearity issues respectively. While path coefficient analysis is to identify the relationship between attitude, subjective norms, perceived behavioral control, and entrepreneurial education towards entrepreneurial intention among KIAS students.

\section{Results and Discussion}

Table 1

Respondent's Demographic Characteristics

\begin{tabular}{lcc}
\hline \multicolumn{1}{c}{ Demographic } & Frequencies & Percentage \\
\hline Gender & 53 & 53 \\
Male & 47 & 47 \\
Female & & \\
Age & & \\
18 and below & 12 & 12 \\
$19-20$ & 47 & 47 \\
21 and above & 41 & 41 \\
& & \\
Status & & 97 \\
Married & 97 & 1 \\
Single & 1 & 2 \\
Others & 2 & \\
& & 87 \\
Ethnicity & & 12 \\
Malay & 87 & \\
Indian & 12 & \\
Chinese & 1 & \\
&
\end{tabular}


Table 2 indicated all items and constructs in this research are reliable and valid. Based on Hair, Hult, Ringle, and Sarstedt (2016) clarified that loading values need to be more than 0.708 . However, the loading value between 0.4 to 0.7 still acceptable if the constructs fulfil the criteria for CR and AVE value. Mean while, the average variance extracted (AVE) value must be more than 0.5 as well as the composite reliability (CR) value must be more than 0.8 as suggested by Hair et al., (2016).

Table 2

The Measurement Model Analysis Result

\begin{tabular}{|c|c|c|c|c|}
\hline Constructs & Item & Loading & CR & AVE \\
\hline \multirow[t]{5}{*}{ Attitude } & AT1 & 0.750 & 0.950 & 0.792 \\
\hline & AT2 & 0.916 & & \\
\hline & AT3 & 0.924 & & \\
\hline & AT4 & 0.938 & & \\
\hline & AT5 & 0.907 & & \\
\hline \multirow[t]{5}{*}{ Subjective Norms } & SN1 & 0.918 & 0.958 & 0.822 \\
\hline & $\mathrm{SN} 2$ & 0.903 & & \\
\hline & SN3 & 0.941 & & \\
\hline & SN4 & 0.879 & & \\
\hline & SN5 & 0.892 & & \\
\hline Perceived & PBC1 & 0.836 & 0.951 & 0.797 \\
\hline Behavioral & $\mathrm{PBC} 2$ & 0.914 & & \\
\hline \multirow[t]{2}{*}{ Control } & $\mathrm{PBC} 3$ & 0.916 & & \\
\hline & PBC4 & 0.921 & & \\
\hline \multirow{5}{*}{$\begin{array}{c}\text { Entrepreneurial } \\
\text { Education }\end{array}$} & EE1 & 0.908 & 0.960 & 0.829 \\
\hline & EE2 & 0.939 & & \\
\hline & EE3 & 0.927 & & \\
\hline & EE4 & 0.870 & & \\
\hline & EE5 & 0.960 & & \\
\hline \multirow{7}{*}{$\begin{array}{c}\text { Entrepreneurial } \\
\text { Intention }\end{array}$} & EI1 & 0.872 & 0.957 & 0.763 \\
\hline & EI2 & 0.885 & & \\
\hline & EI3 & 0.926 & & \\
\hline & EI4 & 0.908 & & \\
\hline & EI5 & 0.920 & & \\
\hline & EI6 & 0.727 & & \\
\hline & EI7 & 0.862 & & \\
\hline
\end{tabular}

The researcher decided to use the Fornell and Larcker criteria as a measurement as suggested by Fornell and Larcker (1980) which is to identify the multicollinearity issues among constructs in this study. The result shows there are fewer multicollinearity issues among constructs whereby the square root of AVE (diagonal) is larger than correlations (offdiagonal) for all constructs as stated Table 3.

Table 3

The Fornell-Lacker Criterion

\begin{tabular}{lccccc}
\hline & ATT & EE & EI & PBC & SN \\
\hline ATT & $\mathbf{0 . 8 9 0}$ & & & & \\
EE & 0.644 & $\mathbf{0 . 9 1 0}$ & & & \\
EI & 0.856 & 0.682 & $\mathbf{0 . 8 7 4}$ & & \\
PBC & 0.621 & 0.574 & 0.651 & $\mathbf{0 . 8 9 3}$ & \\
SN & 0.679 & 0.759 & 0.765 & 0.760 & $\mathbf{0 . 9 0 7}$ \\
\hline
\end{tabular}

Note: ATT: Attitude; EE: Entrepreneurial Education; EI: Entrepreneurial Intention; PBC: Perceived Behavioral Control; SN: Subjective Norms
Path coefficient defined as one the method to identify the level of independent variables towards dependent variable as well as significant impact. In this research, the researchers proposed directional hypotheses which reflected the $t$-value must be more than 1.657 and $p$-value must less than 0.05 in order to accept the hypotheses as suggested by Hair et al., (2016). Based on Table 4, two hypotheses which are attitude and entrepreneurial education significantly towards entrepreneurial intention among KIAS student were accepted since the criteria been fulfilled.

\section{Table 4}

Path Coefficient

\begin{tabular}{ccccc}
\hline Relationship & $\begin{array}{c}\text { Direct Effect } \\
(\beta)\end{array}$ & $\begin{array}{c}\text { Standard } \\
\text { Error }\end{array}$ & $t$-value & $p$-value \\
\hline ATT > EI & 0.608 & 0.079 & 7.703 & 0.000 \\
SN > EI & 0.054 & 0.089 & 0.611 & 0.271 \\
PBC $>$ EI & 0.013 & 0.089 & 0.148 & 0.441 \\
EE $>$ EI & 0.301 & 0.115 & 2.612 & 0.005 \\
\hline
\end{tabular}

Note: ATT: Attitude; EE: Entrepreneurial Education; EI: Entrepreneurial Intention; PBC: Perceived Behavioral Control; SN: Subjective Norms

\section{Discussion}

Based on Table 4, the finding indicated that attitude and entrepreneurial education was positively and significant towards entrepreneurial intention among KIAS student. The path coefficient analysis showed that attitude was positive and significant influence towards entrepreneurial intention among KIAS students. Therefore, the researchers justify that KIAS students consider becoming entrepreneur is a positive attribute and this can be supported by the study from Gitaka (2018) and Gitonga (2017) appended if individuals have greatest intent as entrepreneur if the mindset of become entrepreneur more positive.

Furthermore, the path coefficient indicated that entrepreneurial intention has positive and significant influence by entrepreneurial education among KIAS student. This can justify that entrepreneurial education can be motivator for KIAS students become entrepreneur as future career. The result is similar with the studies from Kabir et al. (2017) and Gitaka (2018) who appended entrepreneurial knowledge provided from institution towards students can be trigger for student intent to become an entrepreneur.

However, the finding in this study indicated that subjective norms and perceived behavioral control does not significantly towards entrepreneurial intention among KIAS student. The researcher justifies that KIAS student that have intent to become entrepreneurial due to self-internal perception includes self-esteem as supported by Kabir et al. (2017) and Nguyen (2017). 
Moreover, the researcher justify that KIAS does not self-confidence and strong belief to perform as entrepreneur since the finding showed no significant between perceived behavioral control and entrepreneurial intention since perceived behavioral control appoint the strength of a person's belief on their capability for successfully performing and executing the roles, task and activities of an entrepreneur (Kabir et al., 2017).

In terms of theoretical contribution, the study capable to provide more understanding about TPB theory in entrepreneurial student context. Furthermore, this study added one variable which is entrepreneurial education with three variables from TPB theory. As result, entrepreneurial education was appropriate in this model since the result indicated entrepreneurial intention was significant from entrepreneurial education. Furthermore, this study capable provide practical contribution for research scholar, government, as well as entrepreneurship educators since this study provided necessary factors become entrepreneur based on young perspectives. In summation, with the aim of increasing students' entrepreneurial interest, the results provided by this study are insightful for entrepreneurial universities by enhancing and designing the entrepreneurial course offering as to be more proactive enough. Additionally, this study also give implication for government by providing funds and useful infrastructures to support and facilitate young generation in the creation of new venture and remove the obstacle in their future career path as well.

There are several future suggestions for this study. First and for all, the target respondents in this study is focus on one institution which is KIAS, Kelantan, Malaysia. Therefore, the future study can be carrying out by another longitudinal research. Furthermore, comparison study can be carrying out by different countries. Since the entrepreneurial education was found significant towards entrepreneurial intention, which indicated that entrepreneurial education can potentially become mediating variable for future study. Moreover, moderator variables such as gender and age can be added for future study. Last but not least, increase number of target respondents might be getting more accurate result since this result just involve 100 target respondents.

\section{Conclusion}

Entrepreneurship is essential for new SMEs startups, developing existing businesses, create job, pursuit innovation and economic growth. KIAS has make a lot of effort to develop the students' entrepreneurial' spirit by providing knowledge and skills to identifying opportunities, generating business ideas as well as developing effective business plan.

Therefore, by understanding the factors that related to students' entrepreneurial intention, it will be more effective in helping students to develop their own business. Moreover, it will help address the current unemployment problem facing by Malaysia graduates. Additionally, researchers suggest that all high education institutions should establish more networking with local as well as international entrepreneurs in conducting business on campus to shape the students' global outlooks. The exposure to the real entrepreneurship environment could help students create favorable intention toward entrepreneurship.

Besides, this study confirmed that the model of TPB combined with entrepreneurial education is appropriate to study entrepreneurial intention. Correlation analysis showed that strength of entrepreneurial intention is significant related with attitude, subjective norms, perceived behavioral control, and entrepreneurial education. This study provided future research opportunity by using the same model to carry out a similar study in other universities as well as private university to increase the statistical relevance of the study and more reliable results. Furthermore, researchers suggested that future research can be develop based on specific entrepreneurial scope categories such as bakery, clothing or shoes store, restaurants and others since every student might have different perceptions based on entrepreneurial scope categories for their career development.

\section{References}

Ajzen, I. (1991). The theory of planned behavior. Behavior and Human Decision Processes 50, 179-211.

Benachenchou, S. M., Arzi, F., \& Omar A. F. (2017). The influence of attitude, subjecttive forms and perceived behavioral control on entrepreneurial intention: Case of Algerian Students. American Journal of Economics, 7(6), 2166-4951.

Botha, M., Carruthers, T. J., \& Venter, M. W. (2019). The relationship between entrepreneurial competencies and the recurring entrepreneurial intention and action of existing entrepreneurs. The Southern African Journal of Entrepreneurship and Small Business Management, 11(1), 1-15.

Cavazos-Arroyo, J., Puente-Díaz, R., \& Agarwal, N. (2017). An examination of certain antecedents of social entrepreneurial intentions among Mexico residents. Revista Brasileira de Gestão de Negócios-RBGN, 19(64), 180199. 
da Cruz, L., Suprapti, S., \& Yasa, K. (2015). Aplikasi theory of planned behavior dalam membangkitkan niat berwirausaha bagi mahasiswa Fakultas Ekonomi Unpaz, Dili Timor Leste. E-Jurnal Ekonomi dan Bisnis Universitas Udayana, 4(12), 895-920.

Dass, A. (2018). The Star online: Young and jobless in Malaysia. Retrieved from https://www.thestar. com.my/business/business-news/2018/08/06/ young-and-jobless-in-malaysia

Dinc, M. S., \& Budic, S. (2016). The impact of personal attitude, subjective norm, and perceived behavioral control on entrepreneurial intentions of women. Eurasian Journal of Business and Economics, 9(17), 23-35.

Ferreras-Garcia, R., Hernández-Lara, A. and SerradellLópez, E. (2019). Entrepreneurial competences in a higher education business plan course. Education + Training, 61(7/8), 850-869.

Fornell, C., \& Larcker, D. F. (1980). The use of canonical correlation analysis in accounting research. Journal of Business Finance \& Accounting, 7(3), 455-474. https://doi.org/0.1111/j.1468-957.1980. tb00213.x

Fritsch, M., Kritikos, A., \& Pijnenburg, K. (2015). Business cycles, unemployment and entrepreneurial entry: Evidence from Germany. International Entrepreneurship and Management Journal, 11(2), 267-286.

Gitaka, J. G. (2018). The role of entrepreneurship education in developing students' entrepreneurial intentions among Kenyan University Students. Doctoral dissertation, United States International University-Africa.

Gitonga, A. N. (2017). Factors influencing entrepreneurial motivation on university student's intentions of becoming entrepreneurs: A case of United States International UniversityAfrica (USIU-A). Doctoral dissertation, United States International University-Africa.

Hair Jr., J. F., Hult, G. T. M., Ringle, C., \& Sarstedt, M. (2016). A primer on partial least squares structural equation modeling (PLS -SEM). Thousand Oaks, CA: Sage publiccations.

Ibrahim, S. B., \& Afifi, O. (2018). Determinants of entrepreneurial intentions using theory of planned behavior. Journal of Economic and Management Science, 19(2), 197-206.

Ismail, M., Ibrahim, A. F., Yaacob, M. R., Ibrahim, A. H., Zakaria, M. N., Razak, R. C., Yusoff, M.N.K., Guan, T.T., \& Kamaruddin, A. N. (2018). Determine entrepreneurial characteristics using mobile android game freezer. International Journal of Interactive Mobile Technologies (iJIM), 12(1), 141-150.

Joseph, I. (2017) Factors influencing international student entrepreneurial intention in Malaysia. American Journal of Industrial and Business Management, 7, 424-428.

Kabir, S. M., Haque, A., \& Sarwar, A. (2017). Factors affecting the intention to become an entrepreneur: A study from Bangladeshi business graduate's perspective. International Journal of Engineering and Information System, 1(6), 10-19.

Mohamad, N., Lim, H.-E., Yusof, N., \& Soon, J.-J. (2015). Estimating the effect of entrepreneur education on graduates' intention to be entrepreneurs. Education + Training, 57(8/9), 874-890.

Nathani, N., \& Dwivedi, G. (2019). Influence of technology entrepreneurship on entrepreneurial intentions: A cross country analysis. Paper presented at Proceedings of $10^{\text {th }}$ International Conference on Digital.

Noor, Y. M., Hong, L. M., Zakaria, A. N. B. I., Nik Mud, N. N. B., \& Yunoh, M. N. M. (2019). The factors influencing small medium enterprise (SMEs) success in Kelantan. International Journal of Innovation, Creativity and Change, 6(3), 55-64.

Ogunlana, F. (2018). The role of entrepreneurship as the driver of economic growth. Centria University of Applied Science.

Rengiah, P., \& Sentosa, I. (2016). An empirial study on the effectiveness of entrepreneurship education in developing entrepreneurial intention among Malaysian university students. Education Journal, 5(4), 53-61.

Suraya, N., Pang, K. X., Aishah, S., \& Zubaibad, S. (2015). The factors influence entrepreneurial intention among undergraduates of University Malaysia Kelantan. Undergraduate Final Year Project Report. University Malaysia Kelantan, Malaysia.

Taha, K. A. S., Ramlan, S. N., \& Noor, I. M. (2017). The fctors affecting entrepreneurial intentions of university students in Malaysia. International Journal of Business and Technopreneurship, 7(2), 189-202.

Tran, A.T.P., \& Von Korflesch, H. (2016). A conceptual model of social entrepreneurial intention based on the social cognitive career theory. Asia Pacific Journal of Innovation and Entrepreneurship, 10(1), 17-38.

Tsai, K. H., Chang, H. C., \& Peng, C. Y. (2016). Extending the link between entrepreneurial self- 
efficacy and intention: A moderated mediation model. International Entrepreneurship and Management Journal, 12(2), 445-463.

Tsordia, C., \& Papadimitriou, D. (2015). The role of theory of planned behavior on entrepreneurial intention of Greek business students. International Journal of Synergy and Research, 4(1), 23 37. https://doi.org/1 0.17951/ijsr. 2015.4.1.23

Usman, B. (2016). A glimpse of entrepreneurial intention: Empirical finding of international students' perspectives in Turkey. Paper presented in International Students Social Sciences Congress (Vol. 29).
Usman, B., \& Yennita (2019). Understanding the entrepreneurial intention among international students in Turkey. Journal of Global Entrepreneurship Research, 9 (10), 1-21. https://doi. org/10.1186/s40497-018-01360

Walter, S. G., \& Block, J. H. (2016). Outcomes of entrepreneurship education: An institutional perspective. Journal of Business Venturing, 31(2), 216-233.

Zhang, F., Wei, L., Sun, H., \& Tung, L. C. (2019). How entrepreneurial learning impacts one's intention towards entrepreneurship. Chinese Management Studies, 13(1), 146-170. https://doi. org/10.1108/CMS-062018-0556. 